\title{
Skin rashes in COVID-19: a report of three cases
}

\section{COVID-19'da deri döküntüleri: üç olgu sunumu}

\author{
(1)Selma Bakar Dertlioğlu \\ University of Health Sciences, Elazığ Training and Research Hospital, Department of Dermatology, Elazı ̆, Turkey
}

Cite this article as/Bu makaleye atıf için: Bakar Dertlioğlu S. Skin rashes in COVID-19: a report of three cases. J Health Sci Med 2020; 3(4): 490-492.

\begin{abstract}
The novel coronavirus disease (COVID-19) that emerged in Wuhan, China in December 2019 quickly escalated to a global pandemic. Several studies have described its typical clinical manifestations, including fever, cough, diarrhea, and fatigue. In this article, we wanted to draw attention to the cutaneous findings associated with COVID-19, to reveal the place of skin findings in the diagnosis of the disease, and to pioneer research on the subject. We examined the skin findings of 3 patients ( 3 female). None had additional disease. Cutaneous findings included urticarial lesions in 1 patient, vesicular lesions on the oral mucosa in 2 patients. Cutaneous rashes in COVID-19 are primarily nonspecific and similar to cutaneous involvement seen in common viral infections. Therefore, dermatologists' differential diagnosis during the Covid-19 outbreak should include Covid-19. Thus, the awareness of dermatologists in the COVID-19 pandemic will increase and it will be provided to avoid delayed or misdiagnosis.
\end{abstract}

Keywords: COVID-19, skin changes, urticaria, enanthema, virus

\section{ÖZ}

Aralık 2019'da Çin'in Wuhan şehrinde ortaya çıkan yeni koronavirüs hastalığı (COVID-19) hızla küresel bir pandemiye dönüştü. Bazı çalışmalarda ateş, öksürük, ishal ve yorgunluk gibi tipik klinik bulgular tanımlanmıştır. Biz bu makalede COVID-19 ile ilişkili kutanöz bulgulara dikkat çekmek, hastalığın tanısında deri bulgularının yerini ortaya koymak ve konuyla ilgili yapılacak araştırmalara öncülük etmek istedik. Üç hastanın (3 kadın) cilt bulgularını inceledik. Hiçbirinde ek hastalık yoktu. Kutanöz bulgular arasında 1 hastada ürtikeryal lezyonlar, 2 hastada oral mukozada veziküler lezyonlar vardı. COVID-19'daki deri döküntüleri spesifik değildi ve yaygın viral enfeksiyonlarda görülen deri bulgularına benzemekteydi. Bu nedenle, dermatologların Covid-19 salgını sırasındaki ayırıcı tanıları Covid-19'u da içermelidir. Böylece dermatologların COVID-19 pandemisinde ki farkındalıkları artarak gecikmiş veya yanlış tanıdan uzaklaşmaları sağlanacaktır.

Anahtar Kelimeler: COVID-19, cilt değişiklikleri, ürtiker, enantem, virüs

\section{INTRODUCTION}

In December 2019, an unexplained outbreak of severe pneumonia occurred in China (1). Suspicion of COVID-19 is based primarily on clinical signs (fever, fatigue, dry cough, anorexia, dyspnea, rhinorrhea, ageusia, anosmia, etc.) and radiology findings. Diagnosis is confirmed by detecting the virus in nasopharyngeal and oropharyngeal swab samples (1). Here, we report the cutaneous manifestations of 3 patients with confirmed diagnosis of COVID-19.

We reviewed electronic medical records, nursing records, laboratory findings, and radiologic examinations for all patients with SARS-CoV-2 infection and collected data on their age, sex, comorbidities (hypertension, diabetes, cardiac or cerebrovascular disease, malignancy, and chronic kidney disease), and typical symptoms from onset to hospital admission (fever, cough, anorexia, diarrhea, throat pain, abdominal pain). All laboratory testing and chest CT were performed according to the clinical care needs of the patient. Visits were made directly or indirectly (due to the high risk of contagion) to collect the patient's history and obtain photographs when possible. Images taken of inpatients'lesions were evaluated remotely using a mobile communication application (WhatsApp). 


\section{CASE REPORTS}

\section{Case 1:}

A 34-year-old woman with no history of urticaria and or angioedema presented with pruritic erythematous plaques on her face and upper body as well as edema of the lips and eyelids (Figure 1). She reported that her edematous rash had started 2 days earlier, followed by dry cough without fever. Her Covid-19 test result was negative but she had radiological findings. Dermatology consultation was requested and the diagnosis of acute urticaria and angioedema was confirmed by a dermatologist. Only antihistaminic therapy was initiated because of the risk of systemic corticosteroids and other immunosuppressants in the infectious process.

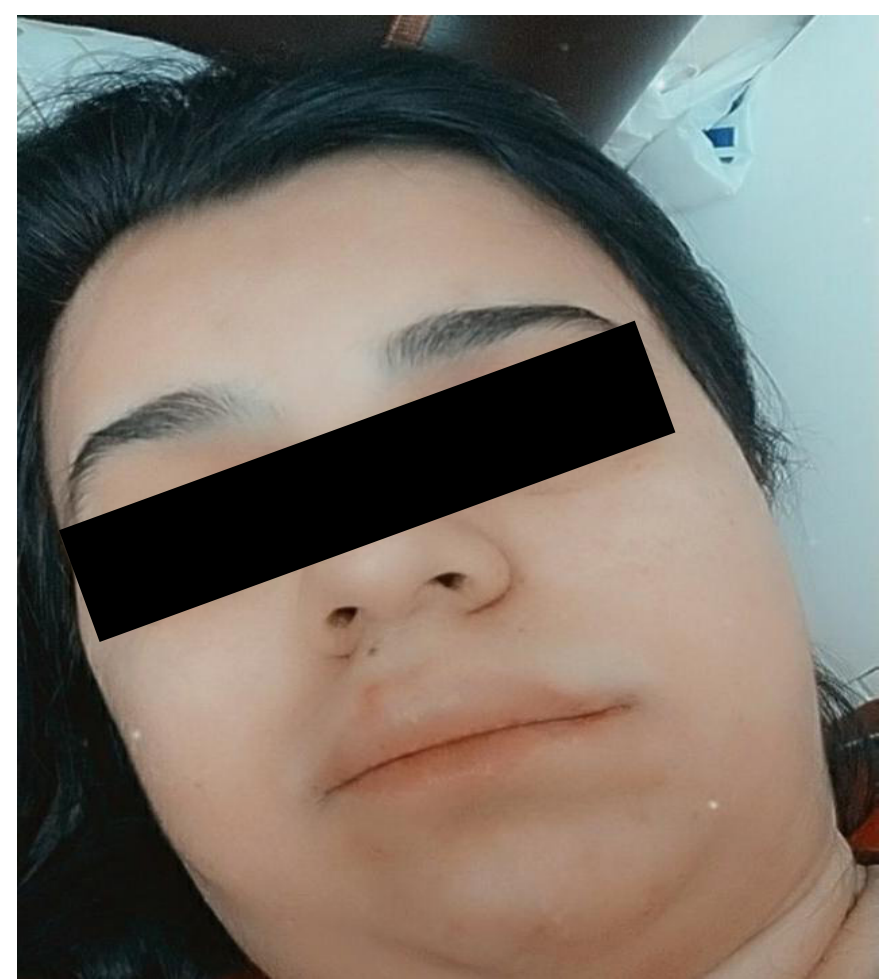

Figure 1. Erythematous plaques on face and upper body as well as edema of the lips and eyelids.

\section{Case 2:}

A 12-year-old girl was admitted to the emergency department with fever, cough, and shortness of breath. She tested positive for COVID-19. Dermatology consultation was requested for the patient based on images sent via WhatsApp. There was a stretched vesicle on the lower lip mucosa (Figure 2). She was hospitalized due to respiratory distress. We also recommended she use antiseptic and analgesic mouthwashes.

\section{Case 3:}

A 43-year-old female healthcare worker suffered from severe dry cough without shortness of breath, arthralgia, myalgia, sore throat, chills, flu-like symptoms, and weakness. Mouth sores appeared at approximately the same time as the onset of these symptoms. She had both intact and ruptured vesicles in the oral mucosa. Her nasopharyngeal and oropharyngeal swab test was positive for COVID-19, while other common viral panels were negative (Figure 3). Treatment with oral hydroxychloroquine $400 \mathrm{mg} / \mathrm{day}$ and azithromycin $500 \mathrm{mg} /$ day was initiated and home isolation was recommended. We also suggested antiseptic and analgesic mouthwash and intensive hydration for her mouth sores.

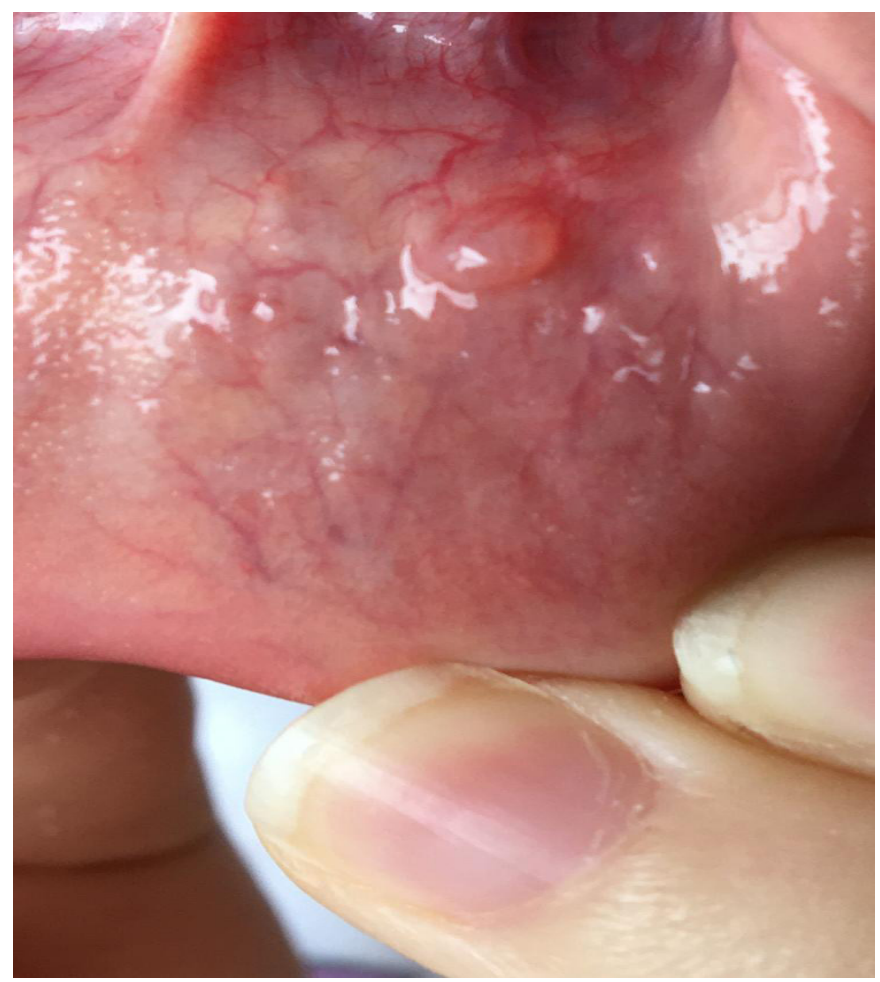

Figure 2. A stretched vesicle on the lip mucosa.

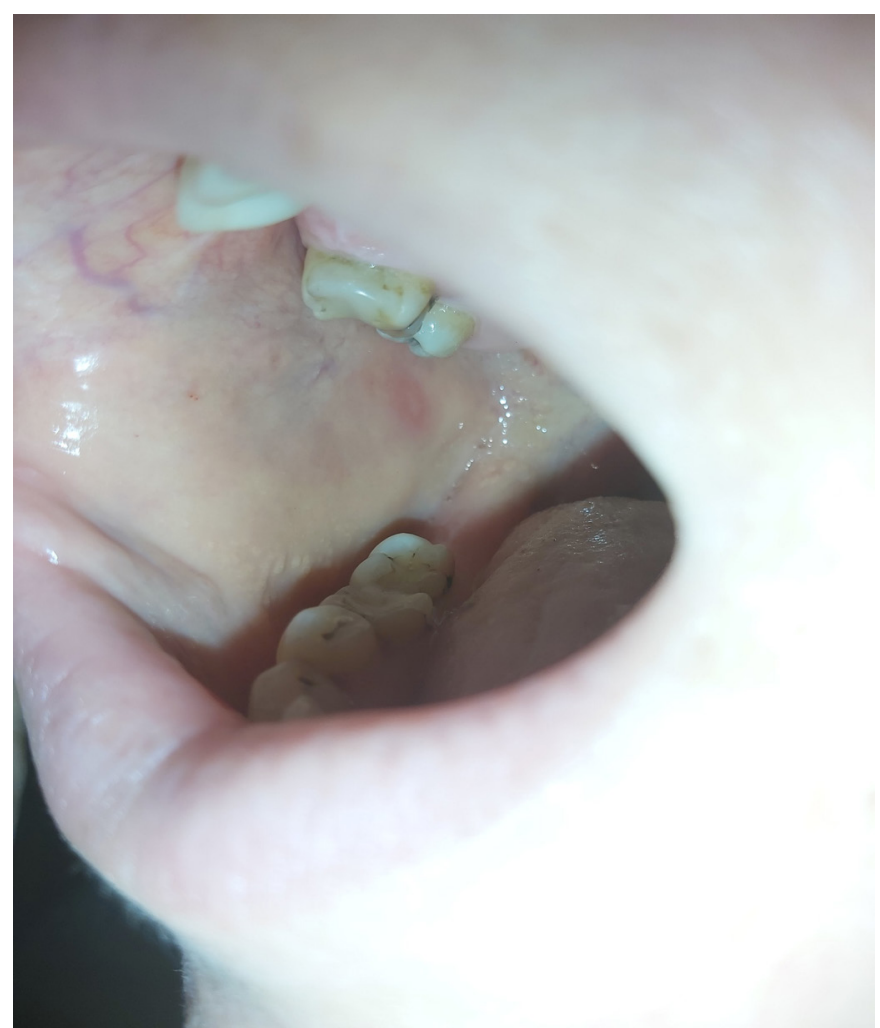

Figure 3. An opened vesicle on the oral mucosa. 


\section{DISCUSSION}

It is possible for COVID-19 patients to initially present with a skin rash that may be misdiagnosed as another disease. Drug reactions, urticaria and enanthema are among its clinical manifestations (2). Erythematous rashes similar to drug reactions were observed in a report, suggesting that dermatologists must also consider COVID-19 in the differential diagnosis of cutaneous drug reactions (3).

In a report, cutaneous findings were observed during COVID-19 infection in 52 of the patients. Urticarial lesion rates were reported as $13.5 \%$ and also enanthema and apthous stomatitis were $5.8 \%$ (4).

A report from Spain presented a 32-year-old woman who had extensive urticariform rash with COVID-19 (5). In another report, a 64 year old female patient was admitted to hospital with difficult breathing, fever and cough. She was diagnosed as COVID-19 and treated with hydroxychloroquine, azithromycine and oseltamivir. During the course of the disease, she had severe urticarial reactions. It was difficult to detect whether the rash was due to the drug or viremia (2). Unlike the previous article; erythematous plaques eruption with particular face and acral involvement were started before fever or any respiratory symptom. So it is essential to take into account and promote the potential recognition among clinicians of this possible skin manifestation of covid-19, and lead to think about testing COVID-19 in these cases (6). In our case, her edematous rash had started 2 days earlier, followed by dry cough without fever. Also she had no history of drug use.

Carreras-Presas et al. (7) published a paper presenting three case reports describing oral mucosa vesiculobullous lesions developed by COVID-19 positive or suspected to be positive patients.

\section{CONCLUSSION}

The COVID-19 patients who presented with skin findings in our study had mild clinical courses. We think it depends on the absence of additional pathologie and their younger age. Nonetheless, clinicians should be aware of these skin symptoms to optimize COVID-19 detection.

\section{ETHICAL DECLARATIONS}

Informed Consent: Written informed consent was obtained from all participants who participated in this study.

Referee Evaluation Process: Externally peer-reviewed.
Conflict of Interest Statement: The authors have no conflicts of interest to declare.

Financial Disclosure: The authors declared that this study has received no financial support.

Author Contributions: All of the authors declare that they have all participated in the design, execution, and analysis of the paper, and that they have approved the final version.

\section{REFERENCES}

1. Li T, Lu H, Zhang W. Clinical observation and management of COVID-19 patients. Emerg Microbes Infect 2020; 9: 687-90.

2. Aktaş H, Hamidi AA. Urticaria in a patient with COVID-19: Therapeutic and diagnostic difficulties [published online ahead of print, 2020 May 17]. Dermatol Ther 2020; e13610. doi:10.1111/ dth.13610.

3. Mahé A, Birckel E, Krieger S, Merklen C, Bottlaender L. A distinctive skin rash associated with coronavirus disease 2019?. J Eur Acad Dermatol Venereol 2020; 34: e246-e247. doi:10.1111/ jdv.16471

4. Askin O, Altunkalem RN, Altinisik DD, Uzuncakmak TK, Tursen U, Kutlubay Z. Cutaneous manifestations in hospitalized patients diagnosed as COVID-19 [published online ahead of print, 2020 Jun 24]. Dermatol Ther 2020; e13896. doi:10.1111/dth.13896.

5. Fernandez-Nieto D, Ortega-Quijano D, Segurado-Miravalles G, Pindado-Ortega C, Prieto-Barrios M, Jimenez-Cauhe J. Comment on: Cutaneous manifestations in COVID-19: a first perspective. Safety concerns of clinical images and skin biopsies. J Eur Acad Dermatol Venereol 2020; 34: e252-e254. doi:10.1111/jdv.16470

6. Henry D, Ackerman M,, Sancelme E,. Finon A, Esteve E. Urticarial Eruption in COVID-19 Infection. J Eur Acad Dermatol Venereol 2020; 34: 244-5. doi:10.1111/jdv.16472.

7. Martín Carreras-Presas C, Amaro Sánchez J, López-Sánchez AF, Jané-Salas E, Somacarrera Pérez ML. Oral vesiculobullous lesions associated with SARS-CoV-2 infection [published online ahead of print, 2020 May 5]. Oral Dis 2020; 10.1111/odi.13382. doi:10.1111/odi.13382.

8. Martín Carreras-Presas C, Amaro Sánchez J, López-Sánchez AF, Jané-Salas E, Somacarrera Pérez ML. Oral vesiculobullous lesions associated with SARS-CoV-2 infection. Oral Dis 2020; 10.1111/ odi.13382. doi:10.1111/odi.13382 